\title{
Antifreeze glycopeptides and peptides in Antarctic fish species from the Weddell Sea and the Lazarev Sea
}

\author{
Andreas P. A. Wöhrmann* \\ Institut für Polarökologie, Kiel University, Wischhofstraße 1-3, Geb. 12, D-24148 Kiel, Germany
}

\begin{abstract}
Antifreeze glycopeptides and peptides have been isolated from 37 species of Antarctic fish representing the families Nototheniidae. Artedidraconidae, Bathydraconidae. Channichthyidae, Muraenolepididae, Liparididae, Zoarcidae and Myctophidae. Amino acid and carbohydrate analysis as well as antifreeze activity indicate that all investigated notothenioids contain antifreeze glycopeptides (AFGP). Pleuragramma antarcticum, Lepidonotothen kempi, Bathydraco marri and Dolloidraco longedorsalis synthesize additional antifreeze molecules. The non-notothenioid species possess antifreeze peptides (AFP), except Muraenolepis marmoratus and Macrourus holotrachys, which possess a glycosylated antifreeze peptide similar to the AFGP found in the notothenioid species. A novel glycopeptide comprised of the carbohydrate residue $\mathrm{N}$-acetylglucosamine and the amino acids asparagine, glutamine, glycine, alanine, and traces of arginine, valine, leucine and threonine was isolated and characterized from $P$. antarcticum. The level of antifreeze concentration was dependent on the ambient water temperature, the depth of catch and life cycle of the species. Antifreeze activity of AFGP varies between 0.52 (Neopagetopsis ionah) and $1.20^{\circ} \mathrm{C}$ ( $P$. antarcticum) at a concentration of $20 \mathrm{mg} \mathrm{ml}^{-1}$ Antifreeze activity of AFP is lower than $0.50^{\circ} \mathrm{C}$. A linear increase in activity of the AFGP could be demonstrated concomitant with decreasing ice content. The structural diversity of antifreeze molecules and their occurrence in a wide range of Arctic and Antarctic fish species suggest that they evolved from precursor proteins before the continental drift and recently during Cenozoic glaciation into the various antifreeze molecules.
\end{abstract}

KEY WORDS: Antifreeze - Notothenioidei - Antarctic fish - Evolution - Pleuragramma

\section{INTRODUCTION}

The sera of marine teleosts are hypoosmotic in relation to seawater, having approximately one-third its molarity of solutes. The colligative effect of the solutes in seawater $(\sim 0.45 \mathrm{M})$ depresses its freezing point to $\mathrm{ca}-1.9^{\circ} \mathrm{C}$, whereas a typical teleost serum will freeze at ca $-0.7^{\circ} \mathrm{C}$ (Holmes \& Donaldson 1969). This discrepancy of ca $1^{\circ} \mathrm{C}$ in freezing points means that unprotected teleosts in polar and northern temperate waters would be at risk of freezing to death when their temperature fell below $-0.7^{\circ} \mathrm{C}$. Although there is evidence that some fish can survive at these temperatures in deep water in a supercooled state (DeVries 1980), this is not possible in

\footnotetext{
•E-mail: npf32@rz.uni-kiel.d400.de
}

shallow water or extremely cold, ice-laden deep water where contact with ice negates supercooling.

So far, 2 types of antifreeze have been isolated from polar and northern temperate fishes. They are either glycopeptides or peptides (AFGP or AFP, respectively). In all of the Antarctic fishes studied to date, with 2 exceptions, the antifreezes are glycopeptides (DeVries \& Lin 1977, Schneppenheim \& Theede 1982, Ahlgren \& DeVries 1984). They have been characterized in detail in the family Nototheniidae of the suborder Notothenioidei. The glycopeptides are made up of a tripeptide repeat (alanine-alanine-threonine) ${ }_{n}$ with a disaccharide moiety attached to the threonyl residues (Komatsu et al. 1970, Shier et al. 1975, Feeney \& Yeh 1978). There are at least 8 different sizes (AFGP 1-8) and the range of molecular weights is between 2600 
and 34000 Da (DeVries et al. 1970, Duman \& DeVries 1976, DeVries 1988). The 3 smaller glycopeptides (AFGP 6-8) differ from the larger ones in that proline replaces the first alanine in the glycotripeptide repeating sequence (Lin et al. 1972, Morris et al. 1978). The same 8 glycopeptides have also been isolated from the gadid Gadus ogac in the Arctic Labrador Sea (Van Voorhies et al. 1978). As more fish have been surveyed for antifreeze activity, 3 distinct AFP types have been characterized in addition to the AFGP (Davies et al. 1988). These are the alanine-rich, $\alpha$-helical AFP of righteye flounders (Pleuronectidae) and sculpins ( $M Y$ oxocephalus sp.) (type I) (Hew et al. 1980, Yang et al. 1988, Davies \& Hew 1990), the cystine-rich AFP of the sea raven (Hemitripterus americanus) (type II) (Slaughter et al. 1981), and an AFP (type III) found in Antarctic and Arctic eel pouts (Zoarcidae) (Hew et al. 1984, Schrag et al. 1987, Cheng \& DeVries 1989) which lacks distinctive features in its composition and sequence.

The AFGP and AFP make up 3.4\% of the blood of many Antarctic fishes. Along with sodium chloride, they lower the fishes' freezing points below that of seawater. On a mass basis, both the glycopeptides and peptides are nearly as effective as sodium chloride in depressing the freezing point of water. On a molar basis, however, they depress the freezing point by 200 to 300 times more than can be expected on the basis of colligative relations alone (DeVries $1971 \mathrm{a}, \mathrm{b})$. The glycopeptides and peptides appear to lower the freezing point only in a non-colligative manner, but show the expected colligative effect on the melting point of the solid phase. The non-colligative lowering of the freezing point has been referred to as an antifreeze effect (also termed thermal hysteresis) and these molecules are referred to as 'antifreezes' (DeVries 1988).

Antarctic fishes inhabiting high-latitude coastal regions of Antarctica are potentially in year-round contact with ice. Seasonality of light, food resources and environmental factors such as water-mass distribution and current patterns also affect the lives of fish in the Antarctic. The Weddell Sea is the largest of several deep embayments of the Antarctic continent. The distribution of the principal water masses in the east wind drift (EWD) and coastal current leads to differentiated temperature conditions on the shelf. Water temperature in the eastern shelf water (ESW) is constantly below $-1.8^{\circ} \mathrm{C}$ (Rohardt et al. 1990). At a depth of $>500 \mathrm{~m}$, oceanic warm deep water (WDW) approaches the shelf and fills the deep trenches and innershelf depressions of the eastern shelf, providing temperatures between $0.0^{\circ}$ and $+0.8^{\circ} \mathrm{C}$ in near-bottom layers. The WDW is not present on the southern shelf or in the Filchner Depression, where cold Antarctic bottom water (ABW) is formed (Seabrooke et al. 1971, Car- mack \& Foster 1975. Fahrbach et al. 1987). During much of the year the surface waters are covered by sea ice, shallow bottoms are covered by anchor ice, and the upper $30 \mathrm{~m}$ of the water column contain small ice crystals.

Both the extremely cold ABW containing platelet ice and the ice-laden shallow water are inhabited by notothenioid and non-notothenioid fish. However, antifreezes are necessary for the evolutionary adaptation of Antarctic fish to the full spectrum of ice-laden habitats. Surprisingly, a few Antarctic notothenioids and non-notothenioids, e.g. Pleuragramma antarcticum, Lepidonotothen kempi, Pogonophryne scotti, Pagetopsis macropterus and liparidids or gadiforms, have been reported to lack antifreezes (DeVries \& Lin 1977. Haschemeyer \& Jannasch 1983, Eastman 1993). What is the reason that antifreezes have been reported as missing in these species living in the Weddell Sea and the Lazarev Sea?

This study provides new information on the distribution, chemical composition and function of AFP and AFGP purified from several members of Notothenioidei and members of the Antarctic fish families Muraenolepididae, Liparididae, Zoarcidae and Myctophidae in relation to ecological habitats, mode of life and evolution. The investigated fishes occupy diverse ecological habitats in the Weddell Sea and the Lazarev Sea, from the WDW up to the cold ice-laden surface water.

\section{MATERIAL AND METHODS}

Fish were collected in 1989 and 1991 during the expeditions ANT VII/4 and ANT IX/3 of the German RV 'Polarstern' in the Weddell Sea and the Lazarev Sea between $69^{\circ}$ and $76^{\circ} \mathrm{S}$ latitude. The fish specimens were caught at 12 stations in water depths between 120 and $1400 \mathrm{~m}$ with a commercial $140 \mathrm{ft}$ bottom trawl and an Agassiz trawl. Detailed information about the cruise and the scientific programmes is given by Hureau et al. (1990), Rankin et al. (1990) and Wöhrmann \& Zimmermann (1992). Species, standard length (SL) and fresh weight (fresh wt) were determined aboard the ship. Species were identified according to the FAO identification sheets (Hureau \& Fischer 1985), nomenclature follows Gon \& Heemstra (1990). Samples were deep frozen at $-80^{\circ} \mathrm{C}$

AFP were isolated as described previously (Wöhrmann 1993, 1995). Samples were passed over Bio-Gel TSK DEAE 5PW (diethylaminoethyl collulose; Bio-Rad) ion exchange resin (column $75 \times 7.5 \mathrm{~mm}$ i.d.), equilibrated with $20 \mathrm{mM}$ Tris- $\mathrm{HCl}, \mathrm{pH} \mathrm{9.5}$, and a salt-concentration gradient $(0.8 \mathrm{M} \mathrm{NaCl}$ in $20 \mathrm{mM}$ Tris- $\mathrm{HCl}$, pH 9.5). Collected fractions were further purified by high-performance liquid chromatography (HPLC) on a 
Vydac C4 reverse-phase column $(5 \mu \mathrm{m}, 250 \times 4.6 \mathrm{~mm})$ A linear acetonitrile gradient was used to elute the peptides and glycopeptides which were detected by absorbance at 215 and $280 \mathrm{~nm}$ (Wöhrmann \& Haselbeck 1992).

Fractions from the ion exchange chromatography were analysed by polyacrylamide gel electrophoresis according to the procedure described by Laemmli (1970), blotted on nitrocellulose according to Burnette (1981) and detected with the lectins peanut agglutinin PNA and wheat germ agglutinin WGA (Haselbeck \& Hösel 1990).

Amino acid analysis was accomplished following acid hydrolysis of the antifreeze peptide in $5 \mu \mathrm{l}$ phenol with $6 \mathrm{~N} \mathrm{HCl}$ at $110^{\circ} \mathrm{C}$ for $24 \mathrm{~h}$ under a nitrogen atmosphere. After hydrolysis the samples were dried in vacuo and analysed on an Applied Biosystems (Foster City, CA, USA) model 420A derivatizer-analyser system. Norleucine was added to each sample as an internal standard.

The carbohydrate residues of antifreeze glycopeptides were analysed using high-performance anionexchange chromatography with pulsed amperometric detection (HPAEC-PAD), consisting of a Dionex BioLC Series 5000 instrument (Dionex Corp., Sunnyvale, CA), a Dionex Bio LC gradient pump, a CarboPac ${ }^{\mathrm{TM}}$ PA-1 (4 × $250 \mathrm{~mm})$ high-resolution strong anion exchange column, and a Model PAD-2 detector

Circular-dichroism (CD) spectra were obtained on a Jasco J-600 spectropolarimeter. The sample cell had a path length of $0.1 \mathrm{~mm}$ and was water jacketed for temperature control. Spectra were taken at $20^{\circ} \mathrm{C}$. The peptide was dissolved in $50 \mathrm{mM} \mathrm{KH}_{2} \mathrm{PO}_{4}, \mathrm{pH} 7.4$, at a concentration of $1 \mathrm{mg} \mathrm{m}^{-1}$.

Samples of reverse-phase HPLC were used for plasma desorption mass spectrometry (PD-MS) analysis. Measurements were performed on a 252Cf plasma desorption time-of-flight mass spectrometer (Applied Biosystems) with a flight tube length of $15 \mathrm{~cm}$. Acceleration voltages were $15 \mathrm{kV}$ in the positive- and negative-ion modes. Spectra measured in the positive and negative ionization modes were accumulated for 10 million fission events each.

The molecular weight was also obtained at $25^{\circ} \mathrm{C}$ by coupling on-line high-performance size exclusion chromatography (HPSEC) and a multi-angle laser light scattering photometer IMALLS detector, a DAWN-F fitted with a $\mathrm{K} 5$ flow cell and a He-Ne laser $(\lambda=$ $632.8 \mathrm{~nm}$ ) from Wyatt Technology Corporation, Santa Barbara, CA]. Proteins were chromatographed on a TSK-gel G3000SW column with an elution buffer $50 \mathrm{mM} \mathrm{KH}_{2} \mathrm{PO}_{4}, 150 \mathrm{mM} \mathrm{NaCl}, \mathrm{pH} 7.0$, and a flow rate of $1.0 \mathrm{mg} \mathrm{ml} \mathrm{m}^{-1}$. Weight average $\mathrm{MW}$ and root-meansquare radii were established with ASTRETTE and EASY software (v. 3.04) (Wyatt 1994).
In this study the differential scanning calorimetry (Perkin-Elmer DSC-7) used to determine antifreeze activity employed direct observation of the sample under slow cooling $\left(1.0^{\circ}\right.$ and $\left.0.1^{\circ} \mathrm{C}\right)$ in the presence of seed ice crystals; these conditions eliminate any supercooling of the sample which may give rise to non-physiological estimates of the freezing point depression. DSC allows for the observation of various thermal events including phase transitions. Analysis of antifreeze peptides or glycopeptides by DSC allowed for rapid assessment of activity which took into account the amount of ice initially present in the sample. With the DSC the thermal hysteresis is defined as the difference between the annealing temperature within the melt zone and the point of ice growth: starting temperature - onset point = antifreeze activity (Hansen et al. 1991).

Samples of AFGP (5, 10 and $20 \mathrm{mg} \mathrm{ml}^{-1}$ ) and AFP (40 and $50 \mathrm{mg} \mathrm{m}^{-1}$ ) from Antarctic fish were dissolved in distilled water and analyzed for antifreeze activity. Samples of approximately $5 \mu \mathrm{l}$ were placed in $10 \mu \mathrm{l}$ aluminum pans. The samples were frozen $\left(-40^{\circ} \mathrm{C}\right.$, $5 \mathrm{~min}$ ) and warmed up to various partial-melt temperatures so that upon subsequent re-cooling $\left(1^{\circ} \mathrm{C} \mathrm{min}^{-1}\right)$ the samples would be inoculated with different amounts of ice. The samples were monitored as they were cooled in the presence of ice. The crystallization temperature and melting-point onset and area for each sample were noted by scanning $1^{\circ} \mathrm{C} \mathrm{min}^{-1}$ between $+10^{\circ}$ and $-40^{\circ} \mathrm{C}$. The amount of ice present in the partial-melt runs was calculated by comparing the freeze area to the complete-melt area. For a detailed reference of all procedures see Wöhrmann (1993 1995).

\section{RESULTS}

As shown in Table 1, all investigated notothenioids possess AFGP but in different concentrations. The highest AFGP content was found in Trematomus pennellii. The lowest content was determined in the benthopelagic channichthyid Neopagetopsis ionah. The maximal thermal hysteresis (antifreeze activity) of AFGP, measured at concentrations of $20 \mathrm{mg} \mathrm{ml}^{-1}$, differ from $0.52^{\circ} \mathrm{C}$ in $N$. ionah to $1.20^{\circ} \mathrm{C}$ in Pleuragramma antarcticum (Fig. 1). P. antarcticum, Lepidonotothen kempi, Bathydraco marri and Dolloidraco longedorsalis possess further AFP of the same concentration as the AFGP. However, the antifreeze activity is lower $(0.41$ to $0.84^{\circ} \mathrm{C}$ at peptide concentration of $40 \mathrm{mg} \mathrm{ml}^{-1}$ ). So far, these peptides could not be further characterized.

Antifreeze substances were also isolated from nonnotothenioid species. Muraenolepis marmoratus, Macrourus holotrachys, Paraliparis somovi and Lycenchelys hureaui synthesize AFP at very low concentrations 
Table 1. Antifreeze peptides (AFP), and glycopeptides (AFGP), region of catch, depth of distribution (m) (after Gon \& Heemstra 1990), and depth of catch (m) of investigated notothenioids and non-notothenioids of the Weddell Sea and the Lazarev Sea. AF: antifreeze substance; \% FRG: antifreeze substance \% fresh weight; TH: thermal hysteresis $\left({ }^{\circ} \mathrm{C}\right)$ of AFGP $\left(20 \mathrm{mg} \mathrm{ml}^{-1}\right)$ and other antifreeze substances (indicated by $\cdot, 50 \mathrm{mg} \mathrm{ml}^{-1}$ )

\begin{tabular}{|c|c|c|c|c|c|c|}
\hline Species & $A F$ & $\begin{array}{c}\% \text { FRG } \\
\left({ }^{\circ} \mathrm{C}\right)\end{array}$ & $\mathrm{TH}$ & Region of catch & $\begin{array}{c}\text { Distribution } \\
\text { (m) }\end{array}$ & $\begin{array}{l}\text { Catch } \\
(\mathrm{m})\end{array}$ \\
\hline \multicolumn{7}{|l|}{ Nototheniidae } \\
\hline Gobionotothen gibberifrons & AFGP & 0.0270 & 0.67 & Elephant Island & $5-750$ & 200 \\
\hline \multirow[t]{2}{*}{ Lepidonotothen kempi } & AFGP & 0.0636 & 0.52 & Lazarev Sea & $100-900$ & 560 \\
\hline & AF II & 0.0598 & $0.73^{\circ}$ & & & \\
\hline Aethotaxis mitopteryx & AFGP & 0.0356 & 0.89 & Lazarev Sea & $100-850$ & 702 \\
\hline \multirow[t]{3}{*}{ Pleuragramma antarcticum } & AFGP & 0.0267 & 1.20 & Weddell Sea & $0-900$ & $450-630$ \\
\hline & AF II & 0.0032 & $0.45^{\circ}$ & & & \\
\hline & PAGP & 0.0143 & $3.21^{\circ}$ & & & \\
\hline Dissostichus mawsoni & AFGP & 0.1053 & 1.10 & Lazarev Sea & $80-1600$ & 626 \\
\hline Trematomus bernacchii & AFGP & 0.1021 & 1.01 & Weddell Sea & $100-700$ & 626 \\
\hline Trematomus eulepidotus & AFGP & 0.1989 & 1.02 & Weddell Sea & $70-550$ & 467 \\
\hline Trematomus lepidorhinus & AFGP & 0.1351 & 0.97 & Weddell Sea & $200-900$ & 617 \\
\hline Trematomus loennbergii & AFGP & 0.1204 & 0.95 & Weddell Sea & $60-830$ & 574 \\
\hline Trematomus pennellii & AFGP & 0.3337 & 1.06 & Lazarev Sea & $0-730$ & 405 \\
\hline \multicolumn{7}{|l|}{ Artedidraconidae } \\
\hline Artedidraco loennbergi & AFGP & 0.0977 & 0.85 & Weddell Sea & $230-600$ & 343 \\
\hline \multirow{2}{*}{ Dolloidraco longedorsalis } & AFGP & 0.0879 & 0.81 & Weddell Sea & $200-2250$ & 626 \\
\hline & AF II & 0.1322 & $0.72^{\circ}$ & & & \\
\hline Pogonophryne marmorata & AFGP & 0.1595 & 0.87 & Weddell Sea & $140-1400$ & 626 \\
\hline Pogonophryne scotti & AFGP & 0.1627 & 0.89 & Weddell Sea & $110-1200$ & 830 \\
\hline Pogonophryne barsukovi & AFGP & 0.1544 & 0.86 & Lazarev Sea & $220-1120$ & 800 \\
\hline Pogonophryne permitini & AFGP & 0.1509 & 0.87 & Lazarev Sea & $430-1120$ & 830 \\
\hline Pogonophryne macropogon & AFGP & 0.1487 & 0.85 & Lazarev Sea & $570-840$ & 830 \\
\hline \multicolumn{7}{|l|}{ Bathydraconidae } \\
\hline \multirow[t]{2}{*}{ Bathydraco marri } & AFGP & 0.0279 & 0.85 & Weddell Sea & $300-1250$ & 623 \\
\hline & AF II & 0.0651 & $0.84^{\circ}$ & & & \\
\hline Bathydraco macrolepis & AFGP & 0.0219 & 0.84 & Lazarev Sea & $450-2100$ & 1400 \\
\hline Bathydraco antarcticus & AFGP & 0.0231 & 0.85 & Lazarev Sea & $320-2250$ & 1400 \\
\hline Gymnodraco acuticeps & AFGP & 0.1973 & 0.90 & Weddell Sea & $0-550$ & 197 \\
\hline Cygnodraco mawsoni & AFGP & 0.1794 & 0.89 & Weddell Sea & $110-300$ & 197 \\
\hline Gerlachea australis & AFGP & 0.1643 & 0.84 & Weddell Sea & $200-670$ & 407 \\
\hline Racovitzia glacialis & AFGP & 0.1147 & 0.84 & Weddell Sea & $220-610$ & 574 \\
\hline \multicolumn{7}{|l|}{ Channichthyidae } \\
\hline Chaenodraco wilsoni & AFGP & 0.2835 & 0.57 & Weddell Sea & $200-800$ & 509 \\
\hline Chionodraco hamatus & AFGP & 0.2576 & 0.80 & Weddell Sea & $0-600$ & 407 \\
\hline Chionodraco myersi & AFGP & 0.1544 & 0.89 & Weddell Sea & $200-800$ & 623 \\
\hline Cryodraco antarcticus & AFGP & 0.0920 & 0.65 & Weddell Sea & $200-800$ & 623 \\
\hline Dacodraco hunteri & AFGP & 0.0809 & 1.00 & Lazarev Sea & $300-800$ & 623 \\
\hline Neopagetopsis ionah & AFGP & 0.0621 & 0.52 & Weddell Sea & $20-900$ & 799 \\
\hline Pagetopsis maculatus & AFGP & 0.1796 & 0.94 & Weddell Sea & $200-800$ & 453 \\
\hline Pagetopsis macropterus & AFGP & 0.2498 & 0.97 & Weddell Sea & $0-650$ & 506 \\
\hline \multicolumn{7}{|l|}{ Muraenolepididae } \\
\hline Muraenolepis marmoratus & $(\mathrm{AFGP})$ & 0.0076 & 0.56 & Lazarev Sea & $20-1600$ & 830 \\
\hline \multicolumn{7}{|l|}{ Macrouridae } \\
\hline Macrourus holotrachys & (AFGP) & 0.0031 & $0.13^{\circ}$ & Lazarev Sea & $150-1100$ & 742 \\
\hline \multicolumn{7}{|l|}{ Liparididae } \\
\hline Paraliparis somovi & AFP & 0.0103 & $0.54^{\circ}$ & Lazarev Sea & $400-850$ & 623 \\
\hline \multicolumn{7}{|l|}{ Zoarcidae } \\
\hline Lycenchelys hureaui & AFP & 0.0041 & $0.18^{\circ}$ & Lazarev Sea & $560-940$ & 830 \\
\hline \multicolumn{7}{|l|}{ Myctophidae } \\
\hline Gymnoscopelus opisthopterus & AFP & 0.0070 & $\sim 0.1^{\circ}$ & Lazarev Sea & $\geq 500$ & 742 \\
\hline
\end{tabular}


Fig. 1. Antifreeze glycopeptides (AFGP) of some investigated Antarctic fish species in relation to water depth and mode of life. Species shown here are representative of most of the ecological habitats of the Weddell Sea and the Lazarev Sea. The concentration of AFGP is given in $\%$ fresh weight, the antifreeze activity $\left({ }^{\circ} \mathrm{C}\right)$ was measured at a protein concentration of $20 \mathrm{mg} \mathrm{ml}^{-1}$ with the differential scanning calorimetry

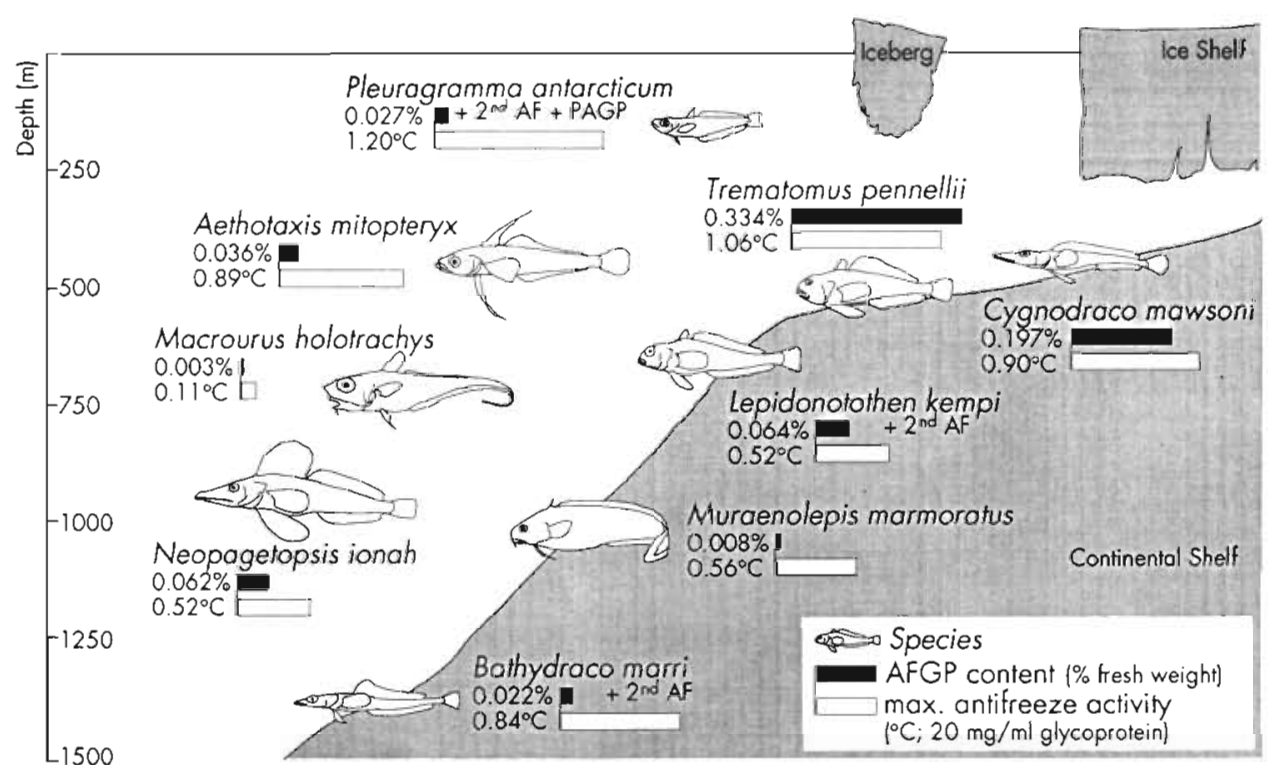

(Table 1); there was no thermal hysteretic effect observed in the blood serum. At peptide concentrations of $40 \mathrm{mg} \mathrm{ml}^{-1}$, antifreeze activity could be measured $\left(0.13^{\circ} \mathrm{C}\right.$ in $M$. holotrachys up to $0.56^{\circ} \mathrm{C}$ in $M$. marmoratus). The antifreeze peptides of $M$. marmoratus and $M$. holotrachys were glycosylated in a fashion similar to that of the AFGP of the notothenioid species (Table 2).

AFGP were also isolated from Pleuragramma antarcticum caught in the southeastern Weddell Sea. The concentration of AFGP is about $80 \%$ less in comparison to other notothenioids from the same region. The results of the amino acid analysis (Table 2) showed that the larger glycopeptides were composed solely of the amino acid residues alanine and threonine in a $2: 1$ ratio. Analysis revealed only alanine and threonine and some proline in the lower molecular weight glycopeptide fractions. Carbohydrate analysis by HPAECPAD also revealed the presence of $\mathrm{N}$-acetylgalactosamine (GalNAc) and galactose (Gal) after acid hydrolysis (trifluoroacetic acid) and of Gal $\beta 1 \rightarrow 3 \mathrm{GalNAc}$ after $\beta$-elimination $\left(\mathrm{NaOH} / \mathrm{NaBH}_{4}\right)$ and treatment with endo- $\alpha-\mathrm{N}$-acetylgalactos-aminidase. The same composition is present in the AFGP of Aethotaxis mitopteryx, Pogonophryne scotti and Pagetopsis macropterus. There is only a minor variation in the proportion of the amino acids alanine to threonine to proline. It seems apparent that although the molecular weights for the AFGP may vary in the range 35000 to $2600 \mathrm{Da}$ from species to species, they still conserve the same structural subunits. The molecular weight of AFGP 7 and 8 were exactly determined by plasma desorption-mass spectrometry at 3277 and $2669 \mathrm{Da}$.

An additional glycopeptide, occurring in concentrations similar to those of the AFGP in Pleuragramma antarcticum, was isolated (Table 2). Amino acid analy- sis of this novel glycopeptide, called PAGP (Pleuragramma-antifreeze glycopeptide), shows glycine (23.9 mol\%), alanine (20.9 mol\%), aspartic acid (17.7 mol\%), glutamic acid (15.8 mol\%) and traces of valine, leucine, arginine and threonine as the amino acids. Sugar analysis by HPAEC-PAD indicate N-acetylglucosamine as carbohydrate residue. The molecular weight of PAGP is approximately $150 \mathrm{kDa}$, the root mean square radius $57.3 \mathrm{~nm}$, as determined by laser-light scattering. The analysis of circular dichroism for PAGP obtained at temperatures of $20^{\circ} \mathrm{C}$ shows $\beta$-sheet $(56 \%)$, $\alpha$-helical (19\%) and random chain (25\%) characteristics. Both AFGP and PAGP are expanded in secondary structure. The antifreeze compounds total $2.46 \mathrm{mg} \mathrm{ml}^{-1}$ blood serum in adult specimens (SL $22 \mathrm{~cm}$ ) of $P$. antarcticum.

There is a variation in the amount of both AFGP and PAGP present in relation to the age of Pleuragramma antarcticum (Fig. 2). Early post-larvae and maturing adults, abundant near the ice shelf in the southeastern Weddell Sea, possess higher antifreeze concentrations (AFGP: 0.283 to $0.295 \%$ fresh wt; PAGP: 0.188 to $0.219 \%$ fresh wt) than juvenile fish feeding on krill in the East Wind Drift (AFGP: $0.279 \%$ fresh wt; PAGP: $0.139 \%$ fresh wt). Moreover, the adult specimens possess the highest concentrations of high molecular weight AFGP $(0.194 \%$ fresh wt).

The antifreeze activity was measured by DSC (Fig. 3). The sample was frozen at $-40^{\circ} \mathrm{C}$, then taken to various annealing temperatures $\left(-0.2\right.$ to $-1.0^{\circ} \mathrm{C}$ for $5 \mathrm{~min}$ ) and cooled again. At $-0.2^{\circ} \mathrm{C}$ no ice was present, and the sample supercooled and crystallized around $-17^{\circ} \mathrm{C}$ (Fig. 3a). While water, non-antifreeze peptides and glycopeptides freeze immediately upon cooling when ice is present, whereas antifreeze glycopeptides 
Table 2. Characteristics of antifreeze glycopeptides of Pleuragramma antarcticum (Pa), Aethotaxıs mitopteryx (Am), Pogonophryne scotti (Ps) and Pagetopsis macropterus $(P m)$ and the antifreeze glycopeptide of Murdenolepis marmoratus (Mm). Amino acid and carbohydrate compositions were determined on the HPLC purified antifreeze components, Molecular weight was determined by SDS polyacrylamide gel electrophoresis, plasma desorption-mass spectrometry and laser light scattering. Thermal hysteresis (TH) was measured by differential scanning calorimetry (DSC) at a scan rate of $1^{\circ} \mathrm{C}$ min ${ }^{-1}$, the secondary structure by circular dichroism

\begin{tabular}{|c|c|c|c|c|c|c|c|}
\hline $\begin{array}{r}\text { Species: } \\
\text { Antifreeze: }\end{array}$ & $\begin{array}{c}P a \\
\text { PAGP }\end{array}$ & $\begin{array}{c}P a \\
\text { AFGP1-5 }\end{array}$ & $\begin{array}{c}P a \\
\text { AFGP6-8 }\end{array}$ & $\begin{array}{l}\text { Am } \\
\text { AFGP }\end{array}$ & $\begin{array}{c}P_{S} \\
\text { AFGP }\end{array}$ & $\begin{array}{c}P m \\
\text { AFGP }\end{array}$ & $\begin{array}{c}M m \\
\text { (AFGP) }\end{array}$ \\
\hline \multicolumn{8}{|l|}{ Amino acid $(\%)$} \\
\hline Aspartic acid & 17.7 & & & & & & 11.0 \\
\hline Glutamic acid & 15.8 & & & & & & 15.7 \\
\hline Serine & & & & & & & 13.7 \\
\hline Glycine & 23.9 & & & & & & \\
\hline Arginine & 5.1 & & & & & & 6.4 \\
\hline Threonine & 3.8 & 38.8 & 34.1 & 33.5 & 33.4 & 34.1 & 18.0 \\
\hline Alanine & 20.9 & 61.2 & 62.4 & 63.6 & 63.5 & 62.6 & 18.4 \\
\hline Proline & & & 3.5 & 2.9 & 3.1 & 3.3 & 10.2 \\
\hline Valine & 6.4 & & & & & & \\
\hline Leucine & 6.2 & & & & & & \\
\hline \multicolumn{8}{|l|}{ Carbohydrate $(\%)$} \\
\hline Galactose & & 50 & 50 & 50 & 50 & 50 & 50 \\
\hline GalNAC & & 50 & 50 & 50 & 50 & 50 & 50 \\
\hline GlcNAC & 100 & & & & & & \\
\hline \multirow{2}{*}{$\begin{array}{l}\text { Molecular weight (Da) } \\
\text { Secondary structure } \\
\text { TH }\left(20 \text { mg ml }{ }^{-1}\right)\left({ }^{\circ} \mathrm{C}\right)\end{array}$} & $\sim 150000^{a}$ & $-34000^{\mathrm{a}, c}$ & $2667^{\mathrm{b} d}$ & \multirow[b]{2}{*}{$\begin{array}{l}\text { expanded in all cases } \\
0.89\end{array}$} & & & \\
\hline & 0.16 & 1.20 & 0.92 & & 0.89 & 0.97 & 0.56 \\
\hline \multicolumn{8}{|c|}{ 'Determined by laser light scattering } \\
\hline \multicolumn{8}{|c|}{${ }^{b}$ Determined by plasma desorption-mass spectrometry } \\
\hline \multicolumn{8}{|c|}{ Molecular weight value is for AFGP1 only } \\
\hline dMolecular weight valu & Ie is for $A F$ & only & & & & & \\
\hline
\end{tabular}

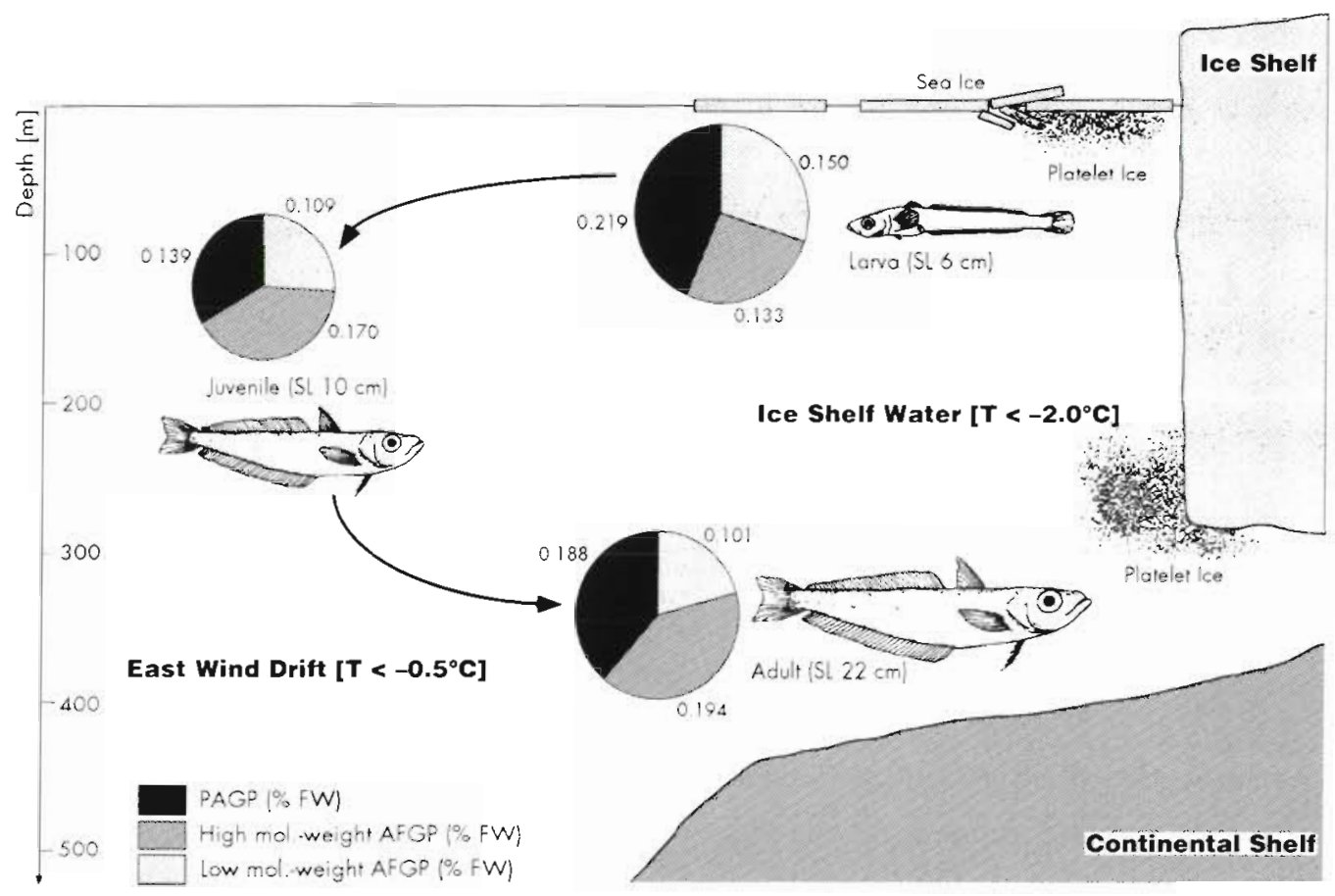

Fig. 2. Antifreeze glycopeptides in Pleuragramma antarcticum in relation to age of fish. AFGP 1-5: high molecular weight fraction; AFGP 6-8: low molecular weight fraction: PAGP: Pleuragramma antifreeze glycopeptide. Age of fish was calculated indirectly using standard length after Hubold \& Tomo (1989) 


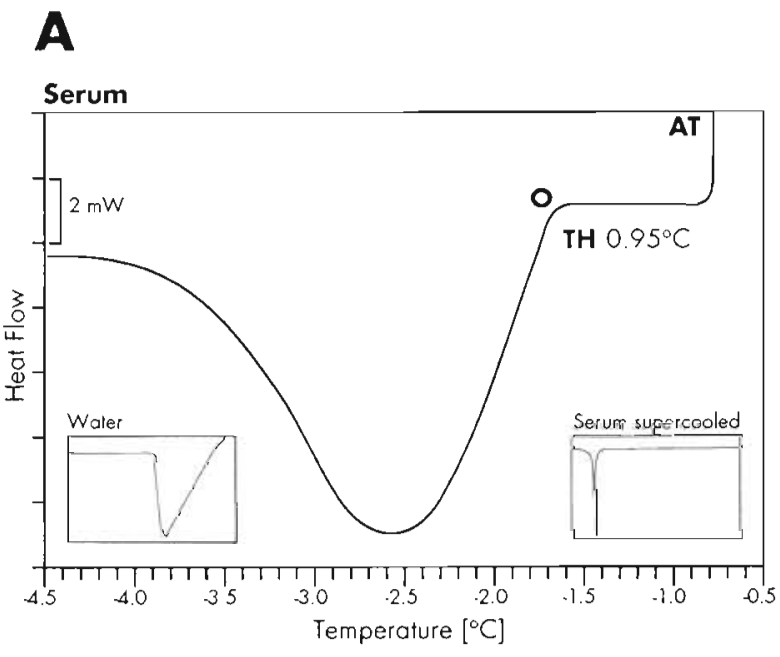

B

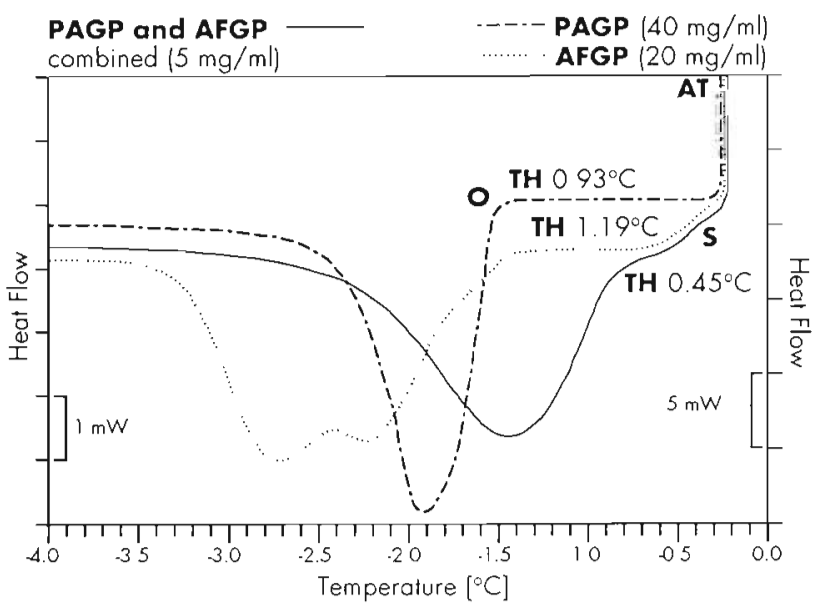

Fig. 3. Differential scanning calorimetry (DSC) of (A) serum and (B) AFGP and PAGP glycopeptides of Pleuragramma antarcticum. Concentrations of 20 and $40 \mathrm{mg} \mathrm{ml}^{-1}(5 \mu \mathrm{ll})$ were tested for antifreeze activity. The typical thermogram revealed a delay in the exotherm onset upon cooling at $1^{\circ} \mathrm{C} \mathrm{min}{ }^{-1}$ Samples that were cooled in the absence of ice supercooled and crystallized at temperatures below $-17^{\circ} \mathrm{C}$. Scale bars next to the thermograms represent heat flow in milliwatts

revealed an initial shoulder $(S)$ upon cooling, followed by a delay before the onset $(O)$ of the freezing exotherm (Fig. 3b). However, a shoulder is not observed when freezing blood serum (Fig. 3a) or the novel PAGP (Fig. 3b); instead, after cooling, there is a long delay before the onset of the freezing exotherm.

Thermal hysteresis seems to be ice-content dependent (Fig. 4). Below 75\% ice content, AFGP demonstrated a linear increase in activity with decreasing ice content. The PAGP has no antifreeze activity at ice concentrations exceeding $60 \%$ and a high activity at low ice content $(<20 \%)$. The serum of Pleuragramma antarcticum shows a very similar thermal hysteresis at

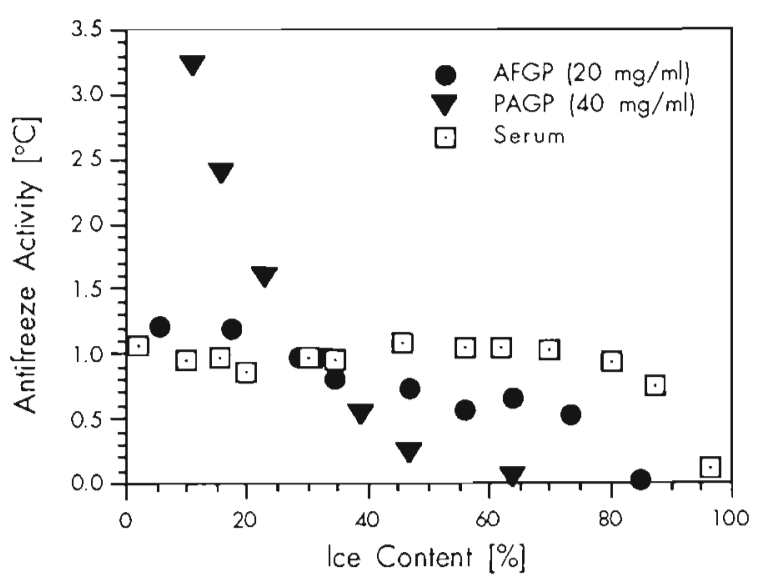

Fig. 4. Graph of antifreeze activity of AFGP, PAGP and blood serum of Pleuragramma antarcticum in relation to the ice content (\%; different annealing temperatures). All samples shown were run at a scan rate of $1.0^{\circ} \mathrm{C} \mathrm{min}-1$

different ice contents up to $80 \%$. The freezing point of the serum is $-1.9^{\circ} \mathrm{C}$ in adult specimens, and hence the same as the freezing point of sea water

As an additional measure of AFGP and PAGP similarity, the amount of thermal hysteresis as a function of protein concentration was measured. As can be seen in Fig. 5, the purified AFGP of Pleuragramma antarcticum show a good agreement with results obtained from the high molecular weight glycopeptides of Dissostichus mawsoni. This again would suggest that the molecular structure of the AFGP is conserved, and that only the number of structural repeating units varies. However, the thermal hysteresis of PAGP increases exponentially with increasing protein concentration.

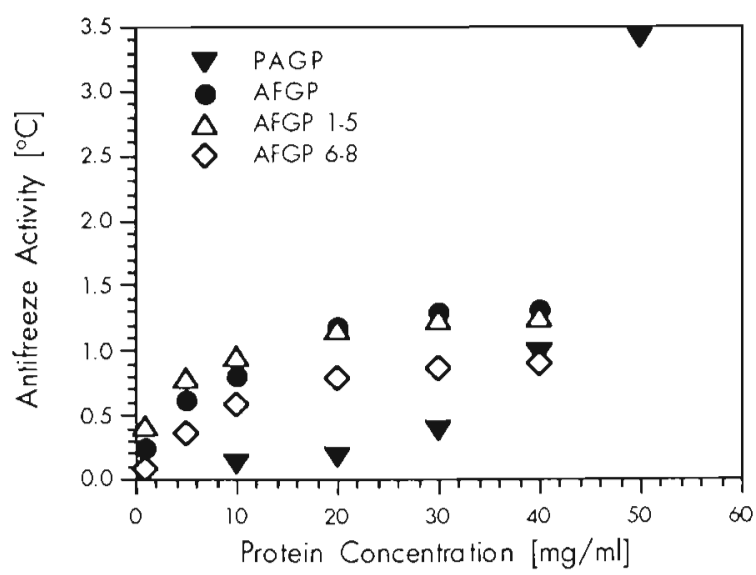

Fig. 5. Comparison of freezing-point depressing activity of the purified glycopeptides AFGP and PAGP of Pleuragramma antarcticum and high (AFGP 1-5) and low (AFGP 6-8) molecular weight fractions of antifreezes from Dissostichus mawsoni in relation to the protem concentration $\left(\mathrm{mg} \mathrm{ml}^{-1}\right)$ 


\section{DISCUSSION}

The Antarctic Ocean hosts little more than 200 coastal fish species (Andriashev 1987, Kock 1992). About $50 \%$ of these species are found exclusively in Antarctic waters and belong to the suborder Notothenioidei (DeWitt 1970). The origin of this suborder dates back to the Lower Tertiary (50 million yr ago, Andersen 1984). Low temperatures have pervaded the Southern Ocean for some 40 million yr (Kennett 1977). Recent data suggest more or less constantly low temperatures $\left(+3^{\circ} \mathrm{C}\right.$ to $-2^{\circ} \mathrm{C}$; Hellmer \& Bersch 1985) since about 13 million yr ago (Eastman \& Grande 1989), which have led to the high degree of stenothermy and endemism of the fish fauna (DeVries \& Eastman 1981).

Most adaptations of Antarctic notothenioids to the cold environment are based on biochemical adjustments (Eastman \& Grande 1989) in metabolic pathways or important cell structures. Some notable examples are increased protein synthesis, low activation energies and enhanced low temperature activities in various enzymes, poorly developed glycolytic pathways combined with an increased role of the pentosephosphate cycle, lipid storage in muscles instead of glycogen deposits, increased membrane fluidity, high conduction velocities and fully compensated synaptic events in the nervous system, and finally, cold-stable microtubules (for review see Macdonald et al. 1987 , Eastman 1993). Antarctic notothenioids fill ecological roles normally occupied by taxonomically diverse fish in temperature waters (Eastman 1991).

The presence of AFP and AFGP in fish is an important adaptation which permits survival in freezing seawater. Because of this adaptation Antarctic fishes are found occupying most ecological niches of the Antarctic Ocean, including the surface and midwaters which are often rich in food but are ice-laden year round for review see DeVries 1988, Cheng \& DeVries 1991, Eastman 1993). Over the past 20 years DeVries and colleagues have isolated antifreezes in 15 species of notothenioids (Eastman 1990) and in 2 non-notothenioid Antarctic species (Cheng \& DeVries 1989, Schrag et al. 1987). The results of this study of additional members of the notothenioids (32 species, Table 1), including the deeper living bathydraconids, channichthyids and non-notothenioid species, reveal that AFGP are common in all Antarctic notothenioids and probably present in the gadiform species Muraenolepis marmoratus and Macrourus holotrachys. It is striking that the amino acid and sugar composition of the isolated AFGP is the same in all those species. The other non-notothenioid species investigated (5 species of 5 families) also possess, without exception, antifreezes, though at very low concentrations.
Thermal hysteresis of antifreezes and blood serum measured by DSC was observed to depend on the amount of ice in the sample. Activity of AFGP of Pleuragramma antarcticum and other notothenioid species remained high at very high ice content, an important factor in the ice-laden water of the Antarctic. Below an ice content of $75 \%$, activity of AFGP increased linearly with decreasing amounts of ice, exhibiting a maximal hysteresis of $1.19^{\circ} \mathrm{C}(8.8 \%$ ice). This behaviour is different from insect AFP (Zachariassen \& Husby 1982, Hansen \& Baust 1988) and PAGP, in which antifreeze activity increased exponentially with decreasing ice content. When the colligative freezing point depression effects of plasma solutes $\left(0.8^{\circ} \mathrm{C}\right.$. Gordon et al. 1962) are added to the maximal thermal hysteretic effect of blood serum $\left(1.06^{\circ} \mathrm{C}\right)$, the resulting protection from freezing $\left(\mathrm{ca}-1.9^{\circ} \mathrm{C}\right)$ is not as high as the lowest water temperature experienced by adult $P$. antarcticum $\left(<-2.0^{\circ} \mathrm{C}\right)$. Adults of this species probably live in a supercooled state, and would freeze upon contact with ice in the surface water at $<-1.9^{\circ} \mathrm{C}$. The data also revealed that the low molecular weight $A F G P$ 6-8 are less active than the high molecular weight AFGP 1-5. Also, the thermograms of AFGP revealed an initial shoulder in the exotherm direction upon cooling which correlates with observed $c$-axis ice growth (Raymond et al. 1989. Hansen et al. 1991); and, the loss of the shoulder during annealing experiments represents the end of the ice growth.

The thermogram of PAGP revealed no shoulder upon cooling, the ice growth is totally blocked. The subsequent exotherm would then be the explosive growth of ice normally observed with other antifreeze assessment techniques (DeVries et al. 1970, Hansen \& Baust 1988). Antifreeze proteins, more appropriately called thermal hysteresis proteins, have also been described in insects (Block \& Duman 1989, Duman et al. 1982). Since overwintering terrestrial insects usually face lower temperatures than fish, their thermal hysteresis proteins can cause a greater lowering of the freezing point than the $1^{\circ} \mathrm{C}$ that appears to be the maximum value for fish AFP and AFGP. However, the highly glycosylated PAGP at high concentrations shows an antifreeze activity of several degrees similar to that which has been reported for crude insect hemolymph. In the hemolymph there are different proteins and other substances depressing the freezing point to such a low level. In PAGP the high content of carbohydrates (N-acetylglucosamine, Table 2 ) probably causes the thermal hysteresis at about $3.4^{\circ} \mathrm{C}$.

In the presence of ice, Antarctic fishes will freeze within a few tenths of a degree of the temperature at which ice will propagate in their blood. It has been shown in earlier investigations that the amount of AFGP present depends upon the fishes' habitats 
(review DeVries 1988). Species like the nototheniid Trematomus pennellii as well as the channichthyid Pagetopsis macropterus or the bathydraconid Gymnodraco acuticeps possess large amounts of AFGP. There is a correlation between the blood freezing point, the concentration and composition of antifreezes, the temperature at which the fish will freeze in the presence of ice, and the habitat of the fish (e.g. water depth). Fishes living in shallow waters which may come in contact with anchor ice have high concentrations of both high and low molecular weight AFGP. They freeze at lower temperatures than those living in icefree deep water such as the non-notothenioid species (e.g. Macrourus holotrachys or Lycenchelys hureaui), which will freeze in surface water at $-1.9^{\circ} \mathrm{C}$. In their natural deep water habitat, these species are in little danger of freezing because of the higher temperature (e.g. $+0.5^{\circ} \mathrm{C}$ on the continental slope in the Lazarev Sea) and because of the effect of hydrostatic pressure which at $500 \mathrm{~m}$ lowers their freezing point to $-2.3^{\circ} \mathrm{C}$, a temperature well below that of the freezing point of seawater. However, in all species investigated, antifreeze molecules could be found.

The snailfish Paraliparis somovi was caught at a depth of $620 \mathrm{~m}$ in the Lazarev Sea, the temperature was about $0.5^{\circ} \mathrm{C}$, no ice was formed in water, and no thermal hysteretic effect could be measured in the blood serum. However, this species possesses nonglycosylated antifreezes in low concentrations. Most Antarctic liparidids are benthic or epibenthic at depths of $300 \mathrm{~m}$ up to $3000 \mathrm{~m}$ (Andriashev 1986). They feed on a variety of invertebrates captured on or near the substrate. In McMurdo Sound, Paraliparis devriesi lives near the bottom at 500 to $650 \mathrm{~m}$ (Andriashev 1986). This species does not possess antifreezes but lives in a supercooled state (Eastman 1993). Paraliparis spp, are in no danger of freezing because of the absence of ice at that water depth, hence the body cannot be seeded by ice crystals (DeVries \& Lin 1977). On the other hand, the presence of antifreezes in $P$. somovi suggests that this species also has the genetic potential to synthesize these peptides.

Near Balleny Island, $1200 \mathrm{~km}$ north of McMurdo Sound, Lepidonotothen kempi inhabits a $+1^{\circ} \mathrm{C}$ layer of water. Slightly shallower and warmer water may have permitted western Antarctic species to become established at Balleny Island. DeVries \& Lin (1977) reported that $L$. kempi does not possess antifreezes. However, $L$. kempi from the Lazarev Sea does synthesize AFGP, but in lower concentrations than other notothenioids from the same region (e.g. Trematomus lepidorhinus, Gymnodraco acuticeps, Dacodraco hunteri). Although the Balleny Island are less than $300 \mathrm{~km}$ off the Victoria Land coast in eastern Antarctica, the fauna lacks eastern Antarctica endemics and includes L. Iarseni, a spe- cies found primarily in western Antarctica and South Georgia (Andriashev 1965, DeWitt 1971). Like the other species distributed at Balleny Island, L. larseni possesses AFGP. Presumably the concentration of AFGP in L. kempi from Balleny Island was too low to be detected by the methods available in the 1970s. It is likely that all species of the genus Lepidonotothen and the L. squamifrons group (Schneppenheim et al. 1994) from the Antarctic Peninsula and the eastern and western Antarctic synthesize antifreezes.

The AFGP content in Bathydraco marri and Dolloidraco longedorsalis is relatively low compared with that of other notothenioids. However, they possess further antifreeze compounds in non-glycosylated peptides. Bathydraconids and artedidraconids are usually referred to as the 'typical high-Antarctic' species (DeWitt 1970) and species of the genus Bathydraco clearly prefer deep and cold areas (Ekau et al. 1986, Schwarzbach 1988, Ekau 1990). Bathydraconids are characteristic of the area of the Filchner depression, which is a deep trench running from the Filchner ice shelf to the continental slope. The prevailing water body is the Ice Shelf Water (ISW) with temperatures as low as $-2.2^{\circ} \mathrm{C}$ and salinities of 34.6 to $34.7 \%$ (Hellmer $\&$ Bersch 1985). The relatively high abundance of bathydraconids in Gould Bay, which is adjacent to the Filchner Depression, could be due to the extremely low temperatures of -2.0 to $-2.2^{\circ} \mathrm{C}$, as proposed by Ekau (1990), or to the high pressure, or a combination of both and the possession of antifreeze compounds in addition to the AFGP.

Aethotaxis mitopteryx and Pleuragramma antarcticum belong to one taxonomic tribe (Pleuragrammiini, along with Cryothenia peninsulae and Gvozdarus svetovidovi; DeWitt et al. 1990), which is the most advanced amongst Nototheniidae and which may have developed fairly recently, possibly less than 10 million yr ago (Andersen 1984). All 4 species are more or less confined to a pelagic/benthopelagic mode of life. Some special adaptations (e.g. neutral buoyancy, antifreeze, blood characteristics) may be of relatively recent origin (Andersen 1984) and could be assigned to recent changes in lifestyle. Apparently, this unique mode of life for fishes, i.e. pelagic and sluggish, seems to be an energy-saving adaptation, providing advantages for fish life in the pelagial or at least not having any obvious disadvantages (Kunzmann 1991, Kunzmann \& Zimmermann 1992). In contrast to A. mitopteryx, P. antarcticum has the PAGP and an additional antifreeze peptide in lower amounts. The content of both AFGP and PAGP seems to depend on the fish's ontogenetic migration and is related to the ambient water temperature (Fig. 2). This is particularly interesting because of the seasonal migration of $P$. antarcticum (Hubold 1985, Gerasimchook \& Lanin 1988). Different water masses 
are crossed during migration and functionally different antifreeze compounds could be helpful when environmental temperature varies.

Most notothenioids are bottom fish confined to water less than $1000 \mathrm{~m}$ deep, although the depth range of individual species may be considerable (Kock 1992). They lack swim bladders, are usually denser than seawater (Eastman \& DeVries 1982, Eastman 1991), and commonly feed and reproduce on the substrate. In an ecological sense, the Southern Ocean is probably underutilized by fishes and could theoretically support more species. Assuming that all Antarctic fish species have the genetic potential to synthesize antifreezes, the low biomass of fish in the water column is due to other environmental factors, such as food supply. The waters south of the Antarctic Convergence are productive during the summer only, and contain relatively few non-notothenioid fish

Of the more than 75 fish species occuring in the Weddell Sea, planktonic stages of less than half are known. Most of these appear only in the surface layer for a short time in the summer (Hubold 1991). There is an established seasonal sequence of species in the summer plankton of the Weddell Sea (Hubold 1990), as well as in other Antarctic areas, e.g. the Bransfield Strait (Kellermann 1989). In winter, pelagic stages of at least 7 species have been found in the Weddell Sea. The pelagic stages and species utilize the relatively high water column production and thus achieve higher stock sizes than the strictly benthic species. They are probably sensitive to environmental changes and represent a relatively young community which evolved in the interglacial periods (DeWitt 1970, Hubold \& Ekau 1987). Planktonic stages concentrate in the surface mixed layer, where feeding conditions seem to be near the optimum, but where there is a risk of contact with ice crystals.

Eastman \& Grande (1989) discussed factors that might have contributed to the paucity of non-notothenioid species in the modern Antarctic ichthyofauna. They concluded that low water temperature was not paramount, and that factors in the realm of ecological constraints were probably at least as important in restricting diversity. Given that antifreezes may have evolved independently several times in the course of evolution, as suggested by the presence of antifreeze peptides in 10 families of 5 suborders, it seems unlikely that low temperature as such has caused the paucity of non-notothenioid species in the Antarctic fish fauna (Clarke 1987, 1990). Rather, the limited shallow water habitat on the continental shelf and seasonal oscillation in the food supply are plausible ecological factors.

The 5 major antifreeze types characterized to date are distributed over 10 families, spanning at least 5 suborders (Fig. 6). Some closely related fish species inhab- iting the same environment produce very different antifreezes, while others belonging to different orders and which are geographically isolated produce essentially identical antifreezes. Scott et al. (1986) suggested that the first antifreeze proteins of marine teleosts were established during the dramatic Cenozoic cooling events initiated approximately 36 million yr ago at the Eocene/ Oligocene boundary (Clarke \& Crame 1992) and that the identical AFGP of Arctic gadiforms, such as Boreogadus saida, and Antarctic notothenioids imply a close relationship. However, Eastman (1993) states that AFGP evolved independently in gadiforms and notothenioids, and that notothenioid AFGP appeared during the past 10 to 15 million $\mathrm{yr}^{\mathrm{r}}$ possibly even later. At the conclusion of the Eocene/Oligocene cooling event at 36 million yr, waters were simply too warm $\left(5\right.$ to $\left.7^{\circ} \mathrm{C}\right)$ to require the presence of AFGP. And, if gadiforms evolved in the Southern Hemisphere and possessed AFGP early in their history, we would expect them to be more extensively represented in the modern Southern Ocean ichthyofauna. However, the present investigation indicates that Antarctic gadiforms also possess AFGP. If this is the case, then AFGP have evolved independently at least 3 times. By contrast, there are no known examples in which unrelated proteins have sufficiently similar (and sufficiently extensive) sequences to warrant the descriptor 'sequence convergence' (Doolittle 1994). If it turns out that the AFGP from Antarctic and Arctic fishes are truly unrelated, this case would have to rate as the nearest thing to sequence convergence yet reported. However, I suggest that, before the continental drift occurred, precursor proteins (e.g. blood proteins or lectins) to the present antifreeze proteins existed and evolved during the Cenozoic cooling events initiated approximately 36 million yr, 16 million yr and 3 million yr ago (Kennett 1977, Clarke 1990) into the various antifreeze peptides and glycopeptides of marine teleosts which are found today.

\section{CONCLUSION}

Freezing resistance is an important adaptation which all Antarctic fishes have successfully developed. All high-Antarctic notothenioids possess AFGP; the nonnotothenioid species, except for the gadiforms Muraenolepis marmoratus and Macrourus holotrachys possess non-glycosylated antifreeze peptides. The ambient water temperature near the freezing point is no selective mechanism for the distribution of Antarctic fish. The discovery, to date, of 5 different antifreeze structures in teleosts, with little relation to their distribution within the currently accepted phylogenetic scheme, has led to the suggestion that more types of antifreezes might be discovered as more species are 


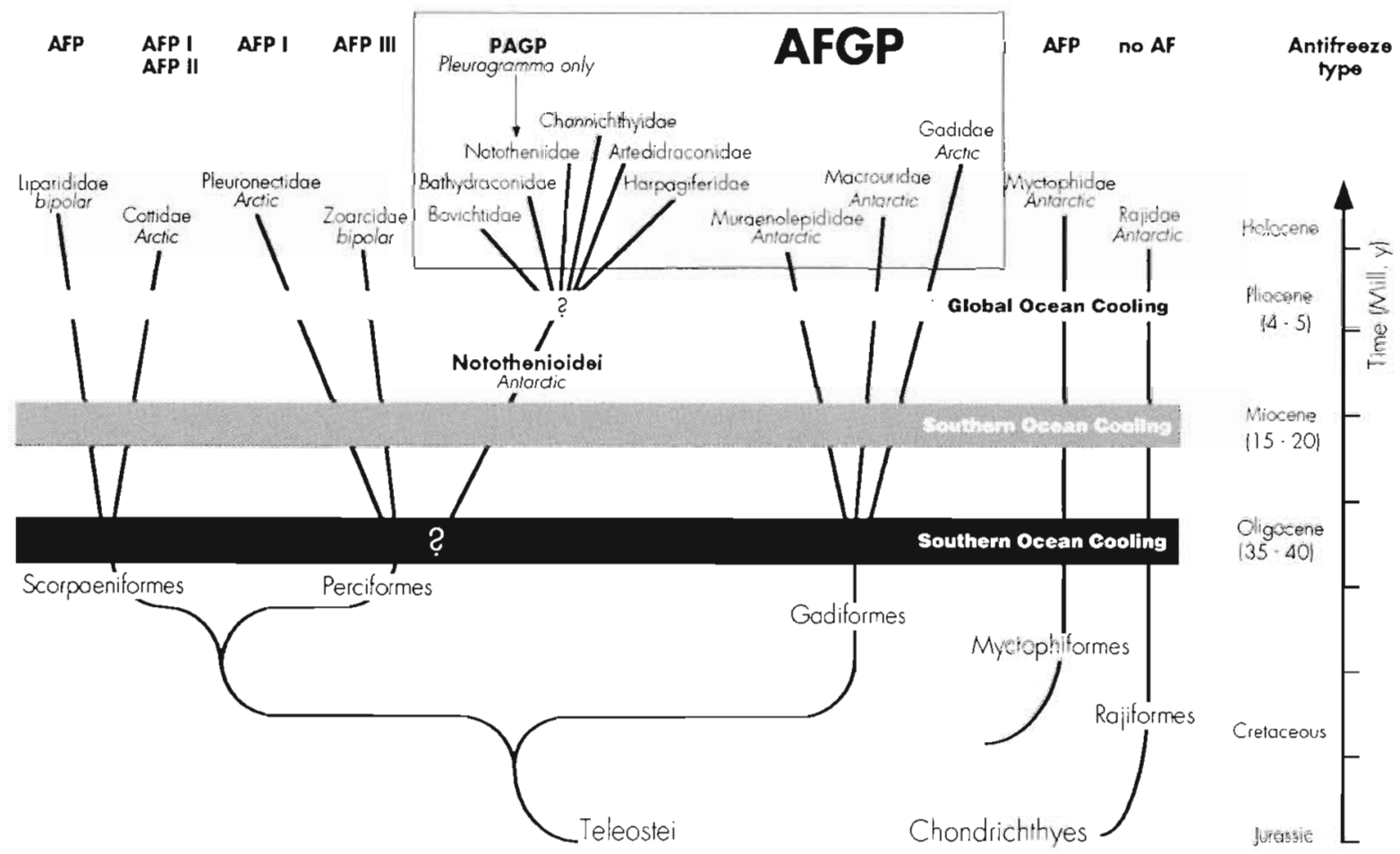

Fig. 6. Schematic outline showing the phylogenetic relationships of present-day fish (after Nelson 1984) that possess antifreeze peptides or glycopeptides. The broad bands at Oligocene, Miocene and Pliocene indicate the onsets of Antarctic and Arctic glaciation (Kennett 1977, Clarke \& Crame 1992)

surveyed. At the present time, cysteine-rich antifreeze proteins in smelt and herring (Ewart \& Fletcher 1990) and further proteins in deep-living notothenioids (Wöhrmann et al. unpubl.) are being characterized. Recent investigations into the genomic organization of antifreeze genes are beginning to offer additional insights into the dynamics of antifreeze evolution. On the one hand, the lineage of the more commonly studied proteins such as globins, crystallins, and cytochrome $c$ can be projected back 108 to 109 million yr ago, i.e. at least some of the fish antifreezes developed as recently as 106 to 107 million yr ago. On the other hand, recent data about the mtDNA variation detected in notothenioid fishes shows it to be too low to agree with the age of notothenioid fishes as suggested by radiation (38 million yr ago) and might instead suggest a younger age (10 to 15 million yr ago) (Bargelloni et al. 1994).

Acknowledgements. I express my thanks to Drs K.-H. Kock, A. Haselbeck and M. Wozny for their helpful discussions and advice, and to C. Zimmermann for the excellent graphic presentations. The technical assistance of Anita Roos and Silke Schneid is gratefully acknowledged. I thank the crew of the RV 'Polarstern' for their skillful support during the cruise. Part of this work was supported by the Deutsche Forschungs Gemeinschaft (DFG) and the European Science Foundation (ESF).

\section{LITERATURE CITED}

Ahlgren JA, DeVries AL (1984) Comparisons of antifreeze glycopeptides from several Antarctic fishes. Polar Biol 3:93-97

Andersen NC (1984) Genera and subfamilies of the family Nototheniidae (Pisces, Perciformes) from the Antarctic and Subantarctic. Steenstrupia 10:1-34

Andriashev AP (1965) A general review of the Antarctic bottom fish fauna. In: van Oye P, van Mieghem $J$ (eds) Biogeography and ecology in Antarctica. Dr W Junk Publishers. The Hague, $\mathrm{p} 491-550$

Andriashev A.P (1986) Review of the snailfish genus Paraliparis (Scorpaeniformes: Liparididae) of the Southern Ocean. Theses Zoologicae, Vol 7. Cramer Verlag, Braunschweig

Andriashev AP (1987) A general review of the Antarctic bottom fish fauna. In: Kullander SO, Fernholm B (eds) Proc 5th Congr Eur Ichthyol. Museum of Natural History, Stockholm, p 357-372

Bargelloni L, Ritchie PA, Patarnello T, Battaglia B, Lambert DM, Meyer A (1994) Molecular evolution at subzero temperatures: mitochondrial and nuclear phylogenies of fishes from Antarctica (suborder Notothenioidei), and the evolution of antifreeze glycopeptides. Mol Biol Evol 11:854-863

Block W, Duman JG (1989) Presence of thermal hysteresis producing antifreeze proteins in the Antarctic mite, Alaskozetes antarcticus. J exp Zool 250:229-231

Burnette WN (1981) Western blotting: electrophoretic transfer of proteins from sodium dodecyl sulfate-polyacrylamide gels to unmodified nitrocellulose and radiographic detection with antibody and radioiodinated protein A. Analyt Biochem 112:195-203 
Carmack EC, Foster TD (1975) Circulation and distribution of oceanographıc properties near the Filchner Ice Shelf. Deep Sea Res 22:77-90

Cheng CC, DeVries AL (1989) Structures of antifreeze peptides from the antarctic eel pout, Austrolycichthys brachycephalus. Biochim Biophys Acta 997:55-64

Cheng CC, DeVries AL (1991) The role of antifreeze glycopeptides and peptides in the freezing avoidance of cold-water fish. In: di Prisco G (ed) Life under extreme conditions. Biochemical adaptation. Springer Verlag, Berlin, p 1-15

Clarke A (1987) The adaptation of aquatic animals to low temperatures. In: Grout BWW, Morris GJ (eds) The effects of low temperatures on biological systems. Edward Arnold, London, p 313-348

Clarke A (1990) Temperature and evolution: Southern Ocean cooling and the Antarctic marine fauna. In: Kerry $K R$, Hempel $G$ (eds) Antarctic ecosystems: change and conservation. Springer Verlag, Berlin, p 9-22

Clarke A, Crame JA (1992) The origin of the Southern Ocean marine fauna. In: Crame JA (ed) Origins and evolution of the Antarctic biota. Spec Publ Geol Soc London 47: $253-268$

Davies PL, Hew CL (1990) Biochemistry of fish antifreeze proteins. FASEB J 4:2460-2468

Davies PL, Hew CL, Fletcher GL (1988) Fish antifreeze proteins: physiology and evolutionary biology. Can J Zool 66: 2611-2617

DeVries AL (1971a) Glycoproteins as biological antifreeze agents in Antarctic fishes. Science 172:1152-1155

DeVries AL (1971b) Freezing resistance in fishes. In: Hoar WS, Randall DJ (eds) Fish physiology, Vol VI. Academıc Press, New York, p 157-190

DeVries AL (1980) Biological antifreezes and survival in freezing environments. In: Gilles $R$ (ed) Animals and environmental fitness. Pergamon Press, Oxford, p 583-607

DeVries AL (1988) The role of antifreeze glycopeptides and peptides in the freezing avoidance of Antarctic fishes. Comp Biochem Physiol B 90:611-621

DeVries AL, Eastman JT (1981) Physiology and ecology of notothenioid fishes of the Ross Sea. J Royal Soc NZ 11. $329-340$

DeVries AL, Komatsu SK, Feeney RE (1970) Chemical and physical properties of freezing point-depression glycoproteins from Antarctic fishes. J Biol Chem 245:2901-2913

DeVries AL, Lin Y (1977) The role of glycoprotein antifreezes in the survival of Antarctic fishes. In: Llano GA (ed) Adaptations within Antarctic ecosystems. Gulf Publishing Co, Gulf, Houston, TX, p 439-458

DeWitt HH (1970) The character of the midwater fish fauna of the Ross Sea, Antarctica. In: Holdgate MW (ed) Antarctic ecology, Vol 1. Academic Press, London, p 305-314

DeWitt HH (1971) Coastal and deep-water benthic fishes of the Antarctic. Antarctic Map Folio Series No 15. American Geophysical Union, Washington

DeWitt HH, Heemstra PC, Gon O (1990) Nototheniidae. In: Gon O. Heemstra PC (eds) Fishes of the Southern Ocean. JLB Smith Institute of Ichthyology, Grahamstown, p 279-331

Doolittle RF (1994) Convergent evolution: the need to be explicit. TIBS 19:15-18

Duman JG. DeVries AL (1976) Isolation, characterization and physical properties of protein antifreezes from the winter flounder, Pseudopleuronectes americanus. Comp Biochem Physiol B 54:375-380

Duman JG. Horwarth KL. Tomchaney A, Patterson JL (1982) Antifreeze agents in terrestrial arthropods. Comp Biochem Physiol A. 73:545-555

Eastman JT (1990) The biology and physiological ecology of notothenioid fishes. In: Gon O, Heemstra PC (eds) Fishes of the Southern Ocean. JLB Smith Institute of Ichthyology, Grahamstown, p 34-51

Eastman JT (1991) Evolution and diversification of Antarctic notothenioid fishes. Am Zool 31:93-109

Eastman JT (1993) Antarctic fish biology. Academic Press, San Diego

Eastman JT, DeVries AL (1982) Buoyancy studies of notothenioid fishes in McMurdo Sound, Antarctica. Copeia 1982: $385-393$

Eastman JT, Grande L (1989) Evolution of the Antarctic fish fauna with emphasis on the recent notothenioids. In: Crame JA (ed) Origins and evolution of the Antarctic biota. Spec Publ Geol Soc London 47:241-252

Ekau W (1990) Demersal fish fauna of the Weddell Sea, Antarctica. Antarct Sci 2:129-137

Ekau W, Hubold G, Wohrmann APA (1986) Fish and fish larvae. Ber Polarforsch 39:210-218

Ewart KV, Fletcher GL (1990) Isolation and characterization of antifreeze proteins from smelt (Osmerus mordax) and Atlantic herring (Clupea harengus harengus), Can J Zool 68:1652-1658

Fahrbach E, Klindt H, Muus D, Rohardt G, Salameh P (1987) Physical oceanography. Ber Polarforsch 39:156-169

Feeney RE, Yeh Y (1978) Antifreeze proteins from fish bloods. Adv Protein Chem 32:191-282

Gerasimchook VV, Lanin VI (1988) On the spatial groupings of the Antarctic sidestripe Pleuragramma antacticum. Vop Ikthiol 28:185-191

Gon O, Heemstra PC (1990) Fishes of the Southern Ocean JLB Smith Institute of Ichthyology, Grahamstown

Gordon MS, Amdur BH, Scholander PF (1962) Freezing resistance in some northern fishes. Biol Bull mar biol. Lab Woods Hole 122:52-62

Hansen TN, Baust JG (1988) Differental scanning calonmetric analysis of antifreeze protein activity in the common mealworm, Tenebrio molitor. Biochim Biophys Acta 957 $217-221$

Hansen TN, DeVries AL, Baust JG (1991) Calorimetric analysis of antifreeze glycoproteins of the polar fish, Dissostichus mawsoni. Biochim Biophys Acta 1079:169-173

Haschemeyer AEV, Jannasch HW (1983) Antifreeze glycopeptides of antarctic fishes. Comp Biochem Physiol B 76 $545-548$

Haselbeck A, Hösel W (1990) Description and application of an immunological detection system for analyzing glycopeptides on blots. Glycoconj J 7:63-74

Hellmer HH, Bersch M (1985) The Southern Ocean. A survey of oceanographic and marine meteorological research work. Ber Polarforsch 26:1-115

Hew CL, Fletcher GL, Ananthanarayanan VS (1980) Antitreeze proteins from the shorthorn sculpin, Myoxocephalus scorpius: isolation and characterization. Can $J$ Biochem 58:377-383

Hew CL, Slaughter D, Joshi SB, Fletcher GL, Ananthanarayanan VS (1984) Antifreeze polypeptides from the Newfoundland ocean pout, Macrozoarces amencanus presence of multiple and compositionally diverse components. J Comp Physiol B 155:81-88

Holmes WN, Donaldson EM (1969) The body compartements and the distribution of electrolytes. In: Hoar WS, Randall DJ (eds) Fish physiology, Vol I. Academic Press, New York, p 1-89

Hubold $G$ (1985) The early life history of the high-Antarctic silverfish, Pleuragramma antarcticum. In: Siegfried WR, Condy PR, Laws RM (eds) Antarctic nutrient cycles and food webs. Springer Verlag, Berlin, p 159-159 
Hubold G (1990) Seasonal patterns of ichthyoplankton distribution and abundance in the southern Weddell Sea. In: Kerry KR, Hempel G (eds) Antarctic ecosystems. Ecological change and conservation. Springer Verlag, Berlin, $p$ $149-158$

Hubold G (1991) Ecology of notothenioid fishes in the Weddell Sea. In: di Prisco G, Maresca B, Tota B (eds) Biology of Antarctic fishes. Springer Verlag, Berlin, p 3-22

Hubold G, Ekau W (1987) Midwater fish fauna of the Weddell Sea, Antarctica. In: Kullander SO, Fernholm B (eds) Proc 5 th Congr European Ichthyologists. Swedish Museum of Natural History, Stockholm, p 391-396

Hubold G. Tomo AP (1989) Age and growth of Antarctic silverfish Pleuragramma antarcticum Boulenger, 1902, from the southern Weddell Sea and Antarctic Peninsula. Polar Biol 9:205-212

Hureau JC, Balguerias E, Duhamel G, Kock KH, OzoufCostaz C. White M (1990) Fish fauna of the eastern Weddell Sea. Ber Polarforsch 68:130-138

Hureau JC, Fischer W (eds) (1985) FAO species identification sheets for fishery purposes. Southern Ocean, Vol Il. FAO, Rome, p 334-335

Kellermann A (1989) The larval fish community in the zone of the seasonal pack-ice cover and its seasonal and interannual variability. Arch FischWiss 39:81-109

Kennett JP (1977) Cenozoic evolution of Antarctic glaciation, the circumantarctic ocean and their impact on global paleoceanography. J Geophys Res 82:3843-3876

Kock KH (1992) Antarctic fish and fisheries. Cambridge University Press, Cambridge

Komatsu SK, DeVries AL, Feeney RE (1970) Studies of the structure of the freezing point-depressing glycoproteins from an Antarctic fish. J Biol Chem 245:2901-2908

Kunzmann A (1991) Blood physiology and ecological consequences in Weddell Sea fishes (Antarctica). Ber Polarforsch 91:1-79

Kunzmann A, Zimmermann C (1992) Aethotaxis mitopteryx, a high-Antarctic fish with benthopelagic mode of life. Mar Ecol Prog Ser 88:33-40

Laemmli UK (1970) Cleavage of structural proteins during the assembly of the head of bacteriophage T4. Nature 227 $680-685$

Lin Y, Duman JG, DeVries AL (1972) Studies on the structure and activity of low molecular weight glycoproteins from an Antarctic fish. Biochem Biophys Res Commun 46:87-92

Macdonald JA, Montgomery JC, Wells RMG (1987) Comparative physiology of Antarctic fishes. Adv mar Biol 24: 321-388

Morris HR, Thompson MR, Osuga DT, Ahmed AI, Chan SM, Vandenheede JR, Feeney RE (1978) Antifreeze glycoproteins from the blood of an Antarctic fish. J Biol Chem 253 $5155-5162$

Nelson JS (1984) Fishes of the world. John Wiley \& Sons, New York

Rankin JC, Johnson T, Kunzmann A, Wöhrmann APA (1990) Physiological studies on teleost fish. Ber Polarforsch 68: $144-152$

This article was submitted to the editor
Raymond JA, Wilson P, DeVries AL (1989) linhibition of growth of nonbasal planes in ice by fish antifreezes. Proc Natl Acad Sci USA 86:881-885

Rohardt G, Ruhland G, Schleif U (1990) The Halley Bay-Kapp Norvegia comparison. Ber Polarforsch 68:39-49

Schneppenheim R, Kock KH, Duhamel G, Janssen G (1994) On the taxonomy of the Lepidonotothen squamifrons group (Pisces, Perciformes, Notothenioidei). Arch Fish mar Res 42:137-148

Schneppenheim R, Theede H (1982) Freezing point depressing peptides and glycopeptides from Arctic-boreal and Antarctic fish. Polar Biol 1:115-123

Schrag JD, Cheng CC, Panico M, Morris HR, DeVries AL (1987) Primary and secondary structure of antifreeze peptides from Arctic and Antarctic zoarcid fishes. Biochim Biophys Acta 915:357-370

Schwarzbach W (1988) The demersal fish fauna of the eastern and southern Weddell Sea: geographical distribution, feeding of fishes and their trophic position in the food web. Ber Polarforsch 54:1-94 (in German)

Scott GK, Fletcher GL, Davies PL (1986) Fish antifreeze proteins: recent gene evolution. Can J Fish Aquat Sci 43: $1028-1034$

Seabrooke IM, Hufford GL, Elder RB (1971) Formation of Antarctic boltom water in the Weddell Sea. J geophys Res $76: 2164-2178$

Shier WT, Lin Y, DeVries AL (1975) Structure of the carbohydrate of antifreeze glycoproteins from an Antarctic fish. FEBS Lett 54:135-138

Slaughter D, Fletcher GL, Ananthanarayanan VS, Hew CL (1981) Antifreeze proteins from the Sea Raven, Hemitripterus americanus. Further evidence for diversity among fish polypeptide antifreezes. J biol Chem 256: $2022-2026$

Van Voorhies WV, Raymond JA, DeVries AL (1978) Glycoproteins as biological antifreeze agents in the cod Gadus ogac (Richardson). Physiol Zool 51:347-353

Wöhrmann APA (1993) Freezing resistance in Antarctic and Arctic fishes. Ber Polarforsch 119:1-99 (in German)

Wöhrmann APA (1995) Antifreeze glycopeptides of the highAntarctic silverfish Pleuragramma antarcticum (Notothenioidei). Comp Biochem Physiol 111C:121-129

Wöhrmann APA, Haselbeck A (1992) Characterization of antifreeze glycoproteins of Pleuragramma antarcticum (Pisces: Notothenioidei). Biol Chem Hoppe-Seyler 373:854

Wöhrmann APA, Zimmermann C (1992) Comparative investigations on fishes of the Weddell Sea and the Lazarev Sea. Ber Polarforsch 100:208-222

Wyatt PJ (1994) DAWN-F, ASTRETTE, EASY instruction manual. Wyatt Technology Corporation, Santa Barbara, CA.

Yang DSC, Sax M, Chakrabartty A, Hew CL (1988) Crystal structure of an antifreeze polypeptide and its mechanistic implications. Nature 333:232-237

Zachariassen KE, Husby JA (1982) Antifreeze effect of thermal hysteresis agents protects highly supercooled insects. Nature 298:865-867

Manuscript first received: November 22, 1994

Revised version accepted: July 3, 1995 